УДК $577.114 ; 663.45$

\title{
Extraction of crude Mannan oligosaccharides from yeast and their uses
}

\author{
R. HARBAH, E. O. AGEMBO, $D$. $S c$. T. V. MELEDINA ${ }^{1}, P h$. $D$. A. S. KRITCHENKOV, V. A. IVANOVA \\ 'tatiana.meledina@yandex.ru \\ ITMO University
}

This review aims to emphasize the importance of mannan oligosaccharides, obtained from various resources especially from yeasts. Attractive features of mannan polysaccharides have had influenced the decisions of food scientists to pursue research on this element, and that may expand their uses and applications in medicine, food industry and animals feed. Food researchers are increasingly focusing on yeast cell wall (YCW) as a promising source of mannan extraction, as the yeast extracts sector generates a huge amount of YCW as a by-product. Extraction is an important method used to obtain the water-soluble mannan oligosaccharides from the wall cells of yeast and in this review was showed the optimal conditions for the extraction of mannan from cell yeast according to results some of the scientific studies along with the deproteinization methods. In the food industry, mannan has various applications such as viscosity modifiers, stabilizers, and increasing the thermo-stability of anthocyanins. Mannan has many health benefits, which have expanded its uses in the medical and pharmaceutical fields. In the animal feed sector, several studies of farm animals have shown significant positive effects of weight gain, reduced bird mortality, and improved fish growth. In pigs, the addition of mannan to pig diets led to obvious economic benefits.

Keywords: mannan, oligosaccharides, yeast cell wall, extraction, prebiotic, food industry, feed additives.

Article info:

Received 25/11/2019, accepted 17/01/2020

DOI: $10.17586 / 1606-4313-2020-19-1-46-51$

Article in English

For citation:

Harbah R., Agembo E. O., Meledina T. V., Kritchenkov A. S., Ivanova V. A. Extraction of crude Mannan oligosaccharides from yeast and their uses. Vestnik Mezhdunarodnoi akademii kholoda. 2020. No 1. p. 46-51.

\section{Экстракция олигосахаридов маннана из дрожжей и их применение}

\author{
Р. ХАРБА, Э. О. АГЕМБО, \\ канд. хим. наук А. С. КРИТЧЕНКОВ, В. А. ИВАНОВА \\ 'tatiana.meledina@yandex.ru \\ Университет ИТМО
}

Рассмотрена роль олигосахаридов маннана, полученных из различных источников, в частности из дрожжеей, поскольку незаменимые свойства полисахаридов маннана дают основание для продолюения исследования этих веществ, позволяющее расиирить их применение в медицине, в пищевой промышленности и в сельском хозяйстве. Исследователи продуктов питания все больще внимания уделяют клеточной стенке дрожжкей (ҮСШ), как перспективному источнику маннана, т. к. при производстве дрожжевых экстрактов огромное количество ҮСШ является побочным продуктом. Экстракция является важным методом, используемым для получения водорастворимых олигосахаридов маннана из клеточных стенок дрожжеей. В обзоре, наряду с депротеинизацией, приведены результаты научных исследований по оптимальным условиям экстракции маннана из клеточных стенок дрожжей. В современной промышленности маннан применяется в качестве модификатора вязкости, стабилизатора, а также для повышение термостабильности антоцианов. Благодаря своим свойствам маннан широко используется в медицине и фармацевтической промышленности. Исследования в области питания сельскохозяйственных животных, при добавлении маннана в рацион питания, показали суцественный прирост их веса, снижение смертности, что привело к очевидным экономическим выгодам.

Ключевые слова: маннан, олигосахариды, клеточная стенка дрожжей, пребиотик, пищевая промышленность, пищевые добавки.

Информация о статье:

Поступила в редакцию 25.11.2019, принята к печати 17.01.2020

DOI: $10.17586 / 1606-4313-2020-19-1-46-51$

Язык статьи - английский

Для цитирования:

Harbah R., Agembo E. O., Meledina T. V., Kritchenkov A. S., Ivanova V. A. Extraction of crude Mannan oligosaccharides from yeast and their uses // Вестник Международной академии холода. 2020. № 1. С. 46-51. 


\section{Introduction}

Undeniably, there has been a growing attention on mannan oligosaccharides (MOS), especially in the fields of nutrition and medicine. Indeed, the polysaccharides isolated from yeast, algae, bacteria, and higher plants have viable features that have influenced the decisions of food scientists to pursue research on these elements. According to Korolenko, Bgatova, and Vetvicka (2019), such attractive features of the various polysaccharides include rare adverse side effects, low toxicity, and relatively low price, among other therapeutic actions [1]. Glucans and mannan remain the most studied polysaccharides in the contemporary research.

The importance of mannan oligosaccharides is undoubtedly colossal and goes beyond uses and applications as both human and animal feed. According to Patel and Goyal (2011), oligosaccharides have been utilised as pharmacological supplements and food ingredients [2]. The authors further emphasize on the effectiveness of functional oligosaccharides in pathogen suppression, immunity enhancement, proliferation of gastrointestinal normal flora, and the prevention of dental caries. Patel and Goyal (2011) also argue that non-digestible oligosaccharides have been useful in such applications like weight control, in bakeries and breweries, as a humectant in confectionaries, and as a sweetener and dietary fiber. Moreover, oligosaccharides have been used in cosmetics, drug delivery, as well as in agriculture, including fishery and animal feed.

Various food companies have used mannan extracts. Montes et al. (2010) emphasized the importance of mannan in ensuring the integrity of the cell wall, as well as adhesion to both cells and tissues [3]. They are also crucial in establishing the immune response of cells, especially using mannan-degrading enzymes. Scientists have successfully obtained mannan oligosaccharides during degradation, as emphasized by Rodriguez-Gacio et al. (2012) [4]. $b$-mannanases, endo- $b 1$ and 4-mannanases were used to achieve the complete degradation process of mannan.

Mannan is present in seminal vacuoles and endosperms, together with non-starch reserve polysaccharides in various plants (Bzducha-Wro' bel et al., 2013 [5]). There is interest in mannan extracted from copra flour, palm kernel and coffee beans (Scheller \& Ulvskov, 2010 [6]). However, the isolation of polysaccharides from the cell wall of microorganisms is more favorable due to their rapid growth and the accumulation of significant amounts of biomass. It should be noted that the production of cellular polysaccharides from waste from fermentation plants is promising. Therefore, interest arose in the isolation, study and application of non-starch polysaccharides of the cell wall of microorganisms in various industries and medicine (Šandula, J. et al., 1999 [7]) in particular yeast of various genera, for example Saccharomyces, Kluyveromyces, Candida (Machova, E. et al., 2015, [8]), Schizosaccharomyces (Varona R., Perez P. \& Duran A., 1983 [9]). Interesting data obtained by Machova, E.; Fiacanova, L.; Cizova, A.; Korcova, J. [8]. The authors showed that the mannanoproteins from yeast Candida albicans consist of comprised $41-46 \%$ of mannan and $47-53 \%$ of protein, while Hyphal mannoproteins comprised $14 \%$ of mannan, $85 \%$ of glucan and $3-4.5 \%$ of protein.

The prominence of MOS as animal feed gained traction since 1999 , primarily after the ban on the growth promoters of prophylactic antibiotic in animal feed by Europe (Spring et al., 2015 [10]). Spring et al. (2015) highlighted the effectiveness of MOS not only in facilitating digestion and immunity but also providing solution for antibiotic-free diets. MOS's characteristic of limiting or binding the colonisation of pathogens in the gut is the main aspect behind such effectiveness.

Studies have also reiterated the importance of MOS in improving gastrointestinal health (Patel \& Goyal, 2011 [2]), thus enhancing the performance (Ganner \& Schatzmayr., 2012 [11]), energy levels, as well as the well-being of humans and animals. MOS has demonstrated effectiveness in improving the growth performance and general health of fish (Torrecillas et al., 2007 [12]; Staykov et al., 2007 [13]; Burr et al., 2008 [14]).

There is growing attention among food scientists towards yeast cell wall (YCW) as a dominant source of bioactive molecules (Li \& Karboune, 2018 [15]), including mannan oligosaccharides and $\beta$-glucan. Undoubtedly, the yeast-extract producing sector is generating a colossal amount of YCW as a by-product. Such production of large amounts of YCW biproduct is attributed to high demand for yeast extract as a flavoring agent, mainly derived from nucleotides, peptides, and amino acids (Chae, Joo, \& In., 2001 [16]). Borchani et al. (2014) argue that YCW is being explored for potential use as a source of beta-glucan and has been utilized extensively as an animal ingredient [17]. Indeed, Huang, Yang, and Wang (2010) described YCW as a «non-specific stimulator of the immune system of both man and animals» [18]. YCW can bind with undesirable components, thereby preventing and curing stuck fermentations.

In doing so, this characteristic of YCW makes it suitable for use in the wine industry. Nonetheless, there has been a little investigation of the extraction of mannoproteins, which constitutes approximately $40 \%, \mathrm{w} / \mathrm{w}$, and are the second-most essential components of the YWC (Quirós et al., 2011 [19]). Similarly, Huang et al. (2005) estimated the contents of mannan oligosaccharides and $\beta$-glucan at 30-60\% of the YCW [20]. Liu et al. (2018) and Lipke \& Ovalle (1998) also reiterated that mannoproteins are not only glycoproteins but also contain as high polysaccharides as $50-95 \%$ [21, 22]. While acknowledging the crucial role of $\beta$-glucan in stimulating macrophages and overcoming bacterial infections, Huang, Yang, and Wang (2010) also emphasize the role of mannan oligosaccharides in preventing diarrhea in weaning pigs [18].

By binding itself to the pathogenic bacteria in the gut, mannan oligosaccharides can get rid of the bacteria out of the intestinal tract (Ganner \& Schatzmayr, 2012 [11]). In so doing, Mannan oligosaccharides are critical in preventing diseases (Fowler et al., 2015 [23]; Kwiatkowski S. \& Kwiatkowski E., 2012 [24]; Van der Werf, 2019 [25]). It is also essential for the growth of the beneficial bacteria in the colon by acting as a nutrient source to the microorganism. Therefore, the current research seeks to explore the techniques of extracting crude mannan oligosaccharides, especially in the wake of the myriad biological functions associated with YCW.

Food researchers are increasingly focusing on yeast cell wall (YCW) as the dominant source of bioactive molecules (Éder Galinari, Diego Araújo Sabry, et al., 2016 [26]) 
(Li \& Karboune, 2018 [15]), including mannan oligosaccharides and $\beta$-glucan. Moreover, this characteristic of YCW makes it suitable for use in the wine industry. Nonetheless, yeast extract is widely used in the food industry and medicine. Undoubtedly, the yeast extract production sector generates an enormous amount of YCW as a by-product. peptides and amino acids (Chae, Joo, \& In, 2001 [16]). Borchani et al. (2014) claim that YCW is being studied for potential use as a source of beta-glucan and is widely used as an ingredient in animal origin [17]. A small study was conducted on the recovery of mannoproteins, which make up approximately $40 \%$ by weight and are the second most important component of the YWC (Quirós et al., 2011 [19]). Similarly, Huang et al. (2005) estimated the content of mannan and $\beta$-glucan oligosaccharides in $30-60 \%$ of YCW [20]. Liu et al. (2018) and Lipke and Ovalle (1998) also confirmed that mannoproteins are not only glycoproteins, but also contain polysaccharides in an amount of 50 to $95 \%$ $[21,22]$. Studies have also confirmed the importance of MOS for improving gastrointestinal health (Patel \& Goyal, $2011[2])$.

Thus, using microorganisms can significantly increase the production of mannan, which is necessary for various industries. Primarily, medicine, livestock, and the food industry (Ganner \& Schatzmayr, 2012 [11]).

Therefore, current research is aimed at studying methods for the extraction of crude mannan oligosaccharides, especially in light of the many biological functions associated with YCW.

\section{Extraction of mannan}

The extraction of mannan oligosaccharides should be studied together with the necessary method of deproteinization, since the majority of mannan in the cell wall exists in the form of a complex mannoprotein.

There are three important methods that can be used to extract pure mannan oligosaccharides and deproteinization, including the Sevage, hydrochloric acid, and trichloroacetic acid methods (Yamabhai et al., 2013 [27]).

The three deproteinization methods operate in different principles. The Sevage method denature dissociative protein using an organic solvent and an insoluble substance. The centrifugation method is applied to pure mannan oligosaccharides (Huang, Yang, \& Wang, 2010 [18]). Similarly, the TCA method operates under the principle that the protein cat-ions have the potential to link the TCA, thus forming an insoluble salt at an isoelectric point. Finally, the hydrochloric acid method of deproteinization is used because of the belief that the protein is soluble at low $\mathrm{pH}$, thus ensuring optimum deproteinization and a slightly higher rate of mannan oligonucleotide loss compared to the other methods.

The extraction water-soluble mannan oligosaccharides from $5 \mathrm{~g}$ yeast is done with the help of $1 \%$ of $50 \mathrm{~mL}$ sodium hydroxide subjected to $100{ }^{\circ} \mathrm{C}$ for two hours (Huang, Yang, \& Wang, 2010 [18]; Yamabhai et al., 2013 [27]). The cooling and neutralizing of the soluble mannan oligosaccharide are done at a $\mathrm{pH}$ of 7 using a diluted chlorine solution (BzduchaWro' bel et al., 2013 [5]). Absolute ethanol $(200 \mathrm{~mL})$ is added to the mannan oligosaccharides to precipitate it after filtration. Both diethyl ether and absolute ethanol are used for washing the precipitate.

\section{The use of mannan in medicine}

Huang, Yang, and Wang (2010) described YCW as a «non-specific stimulator of the human and animal immune systems» [18]. YCW can bind to undesirable components, thereby preventing and eliminating stuck fermentation. The fact of the adsorption of pathogenic microorganisms by mannan was discovered (Li, J. \& Karboune, 2018 [15]).

It has been found that in addition to the action of individual mannan or glucans, glucomannan conjugates contribute to lowering cholesterol and improving immune responses (Onitake, T. et al., 2015 [28]).

The immune-modulating properties of polysaccharides were used to develop new approaches to the prevention and treatment of hyperlipidemia and atherosclerosis. (Korolenko T. A., Johnston TP et al., 2018 [29])

Mannan has probiotic activity and stimulates the growth of selected beneficial intestinal bacteria. These gut bacteria include specific groups such as Lactobacillus spp.

Enterococcus spp., Bifidobacterium spp, etc. (Roberfroid et al., 2010 [30]).

Ghosh, S, et al. emphasized the importance of mannoproteins as a probiotic During the study, which was carried out on calves. The results showed that a prebiotic (mannan oligosaccharide) can be given to calves for better performance (Ghosh, S et al. 2012 [31]).

Loginova and et al showed that the addition of mannan to the intestinal microbiota reduces plasma cholesterol and the development of atherosclerosis. (Loginova et al., 2013 [32]). That is confirmed in recent works by Hoving, L. R and al. (2018) [33].

\section{The use of mannan in livestock, aviculture, and fisheries}

Mannan oligosaccharides are recommended to be used as feed additives. To increase mass gain and improve cattle health, a yeast fraction rich in hydrolyzed mannan and glucan was proposed (Pukrop, J. R. et al., 2018 [34]).

Credence Research (2018) and Spring et al. (2015) found that many feed industries continue to use yeast cells as substitutes for antibiotics [35, 10]. Gene et al. (2018) argue that the immune-modulatory properties of yeast $\beta$-glucans improve the innate and associated adaptive immune system. As noted by Piotrowska and Masek (2015), $\beta$-glucans increase the resistance of livestock to infections because they can bind mycotoxins [36].

In pigs, especially weaned piglets, mannan oligosaccharides have proven useful. Weaned piglets experienced stressful events that could interfere with their immune and intestinal responses, leading to reduced growth, health and feed intake (Campbell et al., 2013 [37]). According to Spring et al. (2015), piglets fed mannan oligosaccharides had an improved feed intake of $1 \%$, a bodyweight of $3.6 \%$, and a feed conversion ratio of $3 \%[10]$. In addition to weaned piglets, feeding sows with mannan oligosaccharides increased litter size and improved colostrum production and quality (Taylor-Pickard, 2015 [38]). Therefore, adding mannan oligosaccharides to pig diets can lead to huge economic benefits.

The benefits of calf mannan oligosaccharides have become critical since they are used as milk substitutes. Mannan oligosaccharides, added to milk and other substitutes, help 
improve feces in these calves because mannan oligosaccharides act as antibiotics (Spring et al., 2015 [10]). As a result, it curbs diarrhea, which is a significant cause of death among young animals. According to Berge et al. (2016) [39], calves treated with mannan oligosaccharides after adding milk to the substitutes reported improved productivity, markedly increased total body weight by $15 \%$ and gained daily body weight by $10 \%$. Thus, mannan oligosaccharides have proven to be extremely important for calf productivity and health. Yeast cell wall supplements in poultry feed have been beneficial. Various studies have shown that birds feeding on yeast cell wall supplements gain weight and report high feed conversion rates (Spring et al., 2015 [10]). Similarly, Hooge et al. (2013) reported a decrease in the mortality rate of birds feeding on manna oligosaccharides [40]. For example, in more than 100 studies with broiler chickens Hooge et al. (2013) noted that broilers that fed mannan oligosaccharides reported improved productivity and increased body weight by $2.0-3.4 \%$ and improved feed conversion ratio by $2.3 \%$. Similarly, turkeys fed on these yeast cell wall supplements reported improved performance.

MOS has been shown to be effective in improving growth and overall health of fish (Torrecillas et al., 2007 [12]; Staykov et al., 2007 [13]; Burr et al., 2008 [14])

\section{The use of mannan in the food industry}

Mannan oligosaccharides have been useful in many sectors, including but not limited to the food industry. Recent studies have reiterated the importance of mannan extracted from YCW. In a survey conducted by Al-Manhel and Niamah (2017) [41], mannan extracts from yeast cells were utilized in the bio-yogurt production. The researchers obtained the mannan extracts from four different sources before mixing them with buffalo milk. In this study, the authors identified the mannan extract using their physiological and morphological properties. The study utilized a probiotic starter culture containing Streptococcus thermophiles, Bifidobacterium sp., and Lactobacillus acidophilus. The outcome of the study reported a decline in the $\mathrm{pH}$ values after fermentation to 4.6-4.8 down, with a total acidity level of $0.89-1 \%$ (Al-Manhel \& Niamah, 2017 [41]). Importantly, mannan extract was useful in the study as it increased the viability of probiotic bacteria, particularly after the yogurt production process.

Jane $\mathrm{Wu}$, and et al found that mannoprotein increases the thermal stability of anthocyanins, which are food colourants with strong antioxidant activities. The study showed that the addition of mannoproteins decreased the degradation rate constant and increased the half-life by 4 to 5 -fold. Thus, mannoproteins can expand the use of anthocyanins as natural colourants (Jane Wu et al., 2015 [42]).

The various properties of mannan, such as water stability, viscosity, and biodegradability may expand it application in the food industry and it can be used as a perfect stiffener and as an emulsion stabilizer, non- toxicity permits their use in different forms for human consumption in food products along with biomedical, and pharmaceutical (Cerqueira, M, A et al., 2011 [43]).

\section{Conclusion}

Mannan is a part of the polysaccharides found in plant tissues, especially hemicelluloses (Bzducha-Wro'bel et al.,
2013 [5]). Both heteromannan and mannan form part of the yeast cell and make up glycoproteins. Therefore, mannan is responsible for metabolic networks, storage, and structural functions.

The importance of mannan oligosaccharides is undoubtedly enormous and goes beyond the use and application as food for humans and animals. In addition, oligosaccharides were used in cosmetics, drug delivery, and agriculture, including fishing and animal feed.

The optimal conditions for the extraction of mannan from cell yeast were when using a $1 \% \mathrm{NaOH}$ solution at a temperature $100{ }^{\circ} \mathrm{C}$ for 2 hours.

There was more loss in the recovery of mannan oligosaccharides using the TCA method and hydrochloric acid method compared with Sevage method, which exhibited a lower percentage of deproteinization, but a little low percentage of polysaccharide loss. That may be due to more evident damage of mannan oligosaccharides caused by TCA and hydrochloric acid, respectively.

The Sevage method is not widely used to remove proteins, because it contains poisonous chloroform, which is environmentally disadvantageous.

\section{References}

1. Korolenko, T. A., Bgatova, N. P. \& Vetvicka, V. (2019). Glucan and Mannan - Two Peas in a Pod. International journal of molecular sciences, 20 (13), 3189.

2. Patel, S. \& Goyal, A. (2011). Functional oligosaccharides: production, properties and applications. World Journal of Microbiology and Biotechnology, 27 (5), 1119-1128.

3. Mora-Montes, H. M., Bates, S., Netea, M. G., Castillo, L., Brand, A., Buurman, E. T. \& Gow, N. A. (2010). A multifunctional mannosyltransferase family in Candida albicans determines cell wall mannan structure and host-fungus interactions. Journal of Biological Chemistry, 285 (16), 12087-12095.

4. Rodri'guez-Gacio, M. C., Iglesias-Fernandez, R., Carbonero, P., \& Matilla, A. J. (2012). Softening-up mannan-rich cell walls. J Exp Bot, 63, 3976-3988.

5. Bzducha-Wro'bel, A., Kieliszek, M., \& Błazejak, S. (2013). Chemical composition of the cell wall of probiotic and brewer's yeast in response to cultivation medium with glycerol as a carbon source. Eur Food Res Technol, 237, 489-499. DOI 10.1007/ s00217-013-2016-8.

6. Scheller, H. V. \& Ulvskov, P. (2010). Hemicelluloses. Annu Rev Plant Biol, 61, 263-89.

7. Šandula, J.; Kogan, G.; Kačuráková, M.; Machová, E. Microbial $(1 \rightarrow 3)-\beta$-d-glucans, their preparation, physico-chemical characterization and immunomodulatory activity. Carbohydr. Polym. 1999, 38, 247-253.

8. Machova, E.; Fiacanova, L.; Cizova, A.; Korcova, J. Mannoproteins from yeast and hyphal form of Candida albicans considerably differ in mannan and protein content. Carbohydr. Res. 2015, 408, 12-17.

9. Varona R., Perez P. \& Duran A. (1983) Effect of papulacandin $\mathrm{B}$ on $\beta$-glucan synthesis in Schizosaccharomyces pombe. FEMS Microbiol. Lett. 20: 243-247.

10. Spring, P., Wenk, C., Connolly, A. \& Kiers, A. A review of 733 published trials on Bio-Mos ${ }^{\circledR}$, a mannan oligosaccharide, and Actigen $\AA$, a second generation mannose rich fraction, on farm and companion animals. Journal of Applied Animal Nutrition, 2015. vol. 3. P. 1-11. 
11. Ganner, A. \& Schatzmayr, G. (2012). Capability of yeast derivatives to adhere enteropathogenic bacteria and to modulate cells of the innate immune system. Appl. Microb. Biotechnol., 95, 289-297.

12. Torrecillas, S., Makol, A., Caballero, M. J., Montero, D., Robaina, L., Real, F. \& Izquierdo, M. S. (2007). Immune stimulation and improved infection resistance in European sea bass (Dicentrarchus labrax) fed mannan oligosaccharides. Fish \& Shellfish Immunology, 23 (5), 969-981.

13. Staykov, Y., Spring, P., Denev, S. \& Sweetman, J. (2007). Effect of a mannan oligosaccharide on the growth performance and immune status of rainbow trout (Oncorhynchus mykiss). Aquaculture International, 15 (2), 153-161.

14. Burr, G., Hume, M., Neill, W. H., \& Gatlin III, D. M. (2008). Effects of prebiotics on nutrient digestibility of a soybean meal based diet by red drum Sciaenops ocellatus (Linnaeus). Aquaculture Research, 39 (15), 1680-1686.

15. Li, J. \& Karboune, S. (2018). A comparative study for the isolation and characterization of mannoproteins from Saccharomyces cerevisiae yeast cell wall. International journal of biological macromolecules, 119, 654-661.

16. Chae, H. J., Joo, H., \& In, M. J. (2001). Utilization of brewer's yeast cells for the production of food-grade yeast extract. Part 1: effects of different enzymatic treatments on solid and protein recovery and flavor characteristics. Bioresource technology, 76 (3), 253-258.

17. Borchani, C., Fonteyn, F., Jamin, G., Paquot, M., Blecker, C., \& Thonart, P. (2014). Enzymatic process for the fractionation of baker's yeast cell wall (Saccharomyces cerevisiae). Food chemistry, 163, 108-113.

18. Huang, G., Yang, Q. \& Wang, Z. B. (2010). Extraction and deproteinization of mannan oligosaccharides. Zeitschrift für Naturforschung C, 65 (5-6), 387-390.

19. Quirós, M., Morales, P., Pérez-Través, L., Barcenilla, J. M. \& Gonzalez, R. (2011). A new methodology to determine cell wall mannoprotein content and release in wine yeasts. Food chemistry, 125 (2), 760-766.

20. Huang, G. L., Liu, M. X. \& Mei, X. Y. (2005). Studies on the hydrolytic condition of $\beta-1,3$ glucan from yeast by fluorophoreassisted carbohydrate electrophoresis. Anal. Lett. 38, 477-485.

21. Liu, H., Li, Y., Shi, A., Hu, H., Sheng, X., Liu, L. \& Adhikari, B. (2018). Rheological characteristics and chain conformation of mannans obtained from Saccharomyces cerevisiae. International journal of biological macromolecules, 107, 2404-2411.

22. Lipke, P. N. \& Ovalle, R. (1998). Cell wall architecture in yeast: new structure and new challenges. Journal of bacteriology, 180 (15), 3735-3740.

23. Fowler, J., Kakani, R., Haq, A., Byrd, J. A., \& Baily, C. A. (2015). Growth promoting effects of prebiotic yeast cell wall products in starter broilers under an immune stress and Clostridium perfringens challenge. J. Appl. Poult. Res. 24, 66-72.

24. Kwiatkowski, S. \& E. Kwiatkowski, E. (2012). Yeast (Saccharomyces cerevisiae) glucan polysaccharides - occurrrence, separation and application in food, feed and health industries. In Karunaratne, D. N. (ed) The complex world of polysaccharides. InTech, pp. 47-70.

25. Van der Werf, M. J. (2019). MOS products: Not every yeast cell wall is created equal. Ohly Application. Retrieved from www. ohly.com/en/feed-health.

26. Éder Galinari, Diego Araújo Sabry, Guilherme Lanzi Sassaki, Gorete Ribeiro Macedo, Flávia Maria Lopes Passos, Hilário Cuquetto Mantovani, Hugo Alexandre Oliveira Rocha. Chemical structure, antiproliferative and antioxidant activities of a cell wall $\alpha$-D-mannan from yeast Kluyveromyces marxianus. Carbohydrate Polymers. 2016. Vol. 157, 1298-1305.

27. Yamabhai, M., Sak-Ubol, S., Srila, W. \& Haltrich, D. (2013). Mannan biotechnology: from biofuels to health. Critical Review in Biotechnology, 1-11.

28. Onitake, T.; Ueno, Y.; Tanaka, S.; Sagami, S.; Hayashi, R.; Nagai, K.; Hide, M.; Chayama, K. Pulverized konjac glucomannan ameliorates oxazolone-induced colitis in mice. Eur. J. Nutr. 2015, 54, 959-969.

29. Korolenko T. A., Johnston T. P., Machova E., Bgatova N. P., Lykov A. P., Goncharova N. V., Nescakova Z., Shintyapina A. B., Maiborodin I. V., Karmatskikh O. L. Hypolipidemic effect of mannans from C. albicans serotypes a and B in acute hyperlipidemia in mice. International Journal of Biological Macromolecules. 2018, 107, 2385-2394.

30. Roberfroid M, Gibson GR, Hoyles L, et al. (2010). Prebiotic effects: metabolic and health benefits. Br J Nutr, 104, s1-s63.

31. Ghosh, S.; Mehla, R. K. Influence of dietary supplementation of prebiotics (mannanoligosaccharide) on the performance of crossbred calves. Trop. Anim. Health Prod. 2012, 44, 617-622.

32. Loginova, V. M.; Tuzikov, F. V.; Tuzikova, N. A.; Korolenko, T. A. Comparative characteristic soflipemia models induced by injections of Triton WR-1339 and poloxamer 407 in mice. Bull. Exp. Biol. Med. 2013, 155 (2), 284-287.

33. Hoving, L. R.; Katiraei, S.; Heijink, M.; Pronk, A.; van der WeePals, L.; Streefland, T.; Giera, M.; Willems van Dijk, K.; van Harmelen, V. Dietary mannan oligosaccharides modulate gut microbiota, increase fecal bile acid excretion, and decrease plasma cholesterol and atherosclerosis development. Mol. Nutr. Food. Res. 2018, 62, e1700942.

34. Pukrop, J. R.; Brennan, K. M.; Funnell, B. J.; Schoonmaker, J. P. Effect of a hydrolyzed mannan and glucan rich yeast fraction on performance and health status of newly received feedlot cattle. J. Anim. Sci. 2018, 96, 3955-3966.

35. Credence Research, Inc. (2018). Global prebiotics market — growth, future prospects, and competitive Analysis, 2018-2026. Retrieved from https://www.credenceresearch.com/report/prebiotics-market.

36. Piotrowska, M. \& Masek, A. (2015). Saccharomyces cerevisiae cell wall components as tools for ochratoxin A decontamination. Toxins. 7, 1151-1162.

37. Campbell, J. M., Crenshaw, J. D., \& Polo, J. (2013). The biological stress of early weaned piglets. J. Anim. Sci. Biotechnol. 4, 19.

38. Taylor-Pickard. (2015). The influence of MOS on sow and piglet performance. Int. Anim. Health J., 2, 60-63.

39. Berge, A. C. (2016). A meta-analysis of the inclusion of Bio-Mos ${ }^{\circledR}$ in milk or milk replacer fed to dairy calves on daily weight gain in the pre-weaning period. J. Animal Res. Nutrition, 1, 19.

40. Hooge, D. M., Kiers, A. \& Connolly, A. (2013). Meta-analysis summary of broiler chicken trials with dietary Actigen ${ }^{\circledR}(2009$ 2011). Int. J. Poultry Sci. 12, 1-8.

41. Al-Manhel, A. J. \& Niamah, A. K. (2017). Mannan extract from Saccharomyces cerevisiae used as prebiotic in bioyogurt production from buffalo milk. International Food Research Journal, 24 (5).

42. Jane Wu, Yongguang Guan, Xin Zhong. (2015). Yeast mannoproteins improve thermal stability of anthocyanins at $\mathrm{pH}$ 7.0, Food chemistry. 172, 121-128.

43. Cerqueira, M. A., Souza, B. W. S., Simoes, J., Teixeira, J. A., Domingues, M. R. M., Coimbra, M. A., Vicente, A. A. (2011). Structural and thermal characterization of galactomannans from non-conventional sources. Carbohydrate Polymers. 83, 179-185. 


\section{Сведения об авторах}

\section{Харба Разан}

Аспирант факультета пищевых биотехнологий и инженерии Университета ИТМО, 191002,

Санкт-Петербург, ул. Ломоносова, 9

\section{Агембо Эванс Одонго}

Магистрант факультета пищевых биотехнологий и инженерии Университета ИТМО, 191002,

Санкт-Петербург, ул. Ломоносова, 9

\section{Меледина Татьяна Викторовна}

Д. т. н., профессор факультета пищевых биотехнологий и инженерии Университета ИТМО, 191002,

Санкт-Петербург, ул. Ломоносова, 9, SPIN-код: 5771-8409,

Author ID: 381606, tatiana.meledina@yandex.ru

\section{Критченков Андрей Сергеевич}

К. х. н., доцент факультета пищевых биотехнологий и инженерии Университета ИТМО, 191002, Санкт-Петербург, ул. Ломоносова, 9, Scopus ID: 37074913200,

РИНЦ ID: 705940, ORCID: 0000-0002-6411-5988, platinist@mail.ru

\section{Иванова Вера Анатольевна}

Аспирант факультета пищевых биотехнологий и инженерии Университета ИТМО, 191002, Санкт-Петербург,

\section{Information about authors}

\section{Harbah Razan}

Graduate student of the Faculty of Food Biotechnology and Engineering of ITMO University, 191002, Russia, St. Petersburg, Lomonosov str., 9

\section{Agembo Evans Odongo}

Ungraduated of the Faculty of Food Biotechnology and Engineering of ITMO University, 191002, Russia, St. Petersburg, Lomonosov str., 9

Meledina Tatyana V.

D. Sc., Professor of the Faculty of Food Biotechnology and Engineering of ITMO University, 191002, Russia, St. Petersburg, Lomonosov str., 9, SPIN-код: 5771-8409, Author ID: 381606, tatiana.meledina@yandex.ru

\section{Kritchenkov Andrey S.}

Ph. D., Associate professor of the Faculty of Food Biotechnology and Engineering of ITMO University, 191002, Russia, St. Petersburg, Lomonosov str., 9, Scopus ID: 37074913200, ORCID: 0000-0002-6411-5988, platinist@mail.ru

Ivanova Vera A.

Graduate student of the Faculty of Food Biotechnology and Engineering of ITMO University, 191002, Russia, St. Petersburg, Lomonosov str., 9

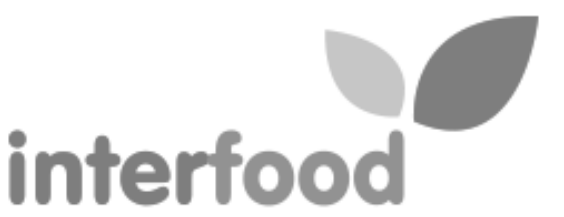

ST.PETERSBURG

\section{Выставка продуктов питания и напитков InterFood St.Petersburg}

\section{4-15 апреля 2020 г.}

РАЗДЕЛЫ ВЫСТАВКИ:

$\begin{array}{ll}\checkmark & \text { Кондитерские и хлебобулочные изделия; } \\ \checkmark & \text { Мясные и колбасные изделия; } \\ \checkmark & \text { Молочная продукция; } \\ \checkmark & \text { Рыба и морепродукты; } \\ \checkmark & \text { Овощи и фрукты; } \\ \checkmark & \text { Масложировая продукция; } \\ \checkmark & \text { Консервация; } \\ \checkmark & \text { Мороженое; }\end{array}$

Организатор выставки:

Компания MVK

190000, Россия, Санкт-Петербург,

Конногвардейский бул., д. 4, лит. А

+7 (812) 3806000 $\checkmark$ Спортивное питание;

$\checkmark$ Детское питание;

$\checkmark$ Здоровое питание;

$\checkmark$ Снеки, орехи, сухофрукты;

$\checkmark$ Специи и соусы;

$\checkmark$ Чай и кофе;

$\checkmark$ Безалкогольные напитки;

$\checkmark \quad$ Полуфабрикаты и замороженные продукты.

Место проведения: Санкт-Петербург, Петербургское шоссе, 64/1, КВЦ "ЭКСПОФОРУМ" http://www.interfood-expo ru/ 